\title{
Trophic structure of vermetid reef community: High trophic diversity at small spatial scales
}

\author{
Francesca Colombo ${ }^{a, *}$, Valentina Costa ${ }^{a, b}$, Stanislas F. Dubois ${ }^{c}$, Paola Gianguzza ${ }^{a}$, \\ Antonio Mazzola ${ }^{a}$, Salvatrice Vizzini ${ }^{a}$
}

\footnotetext{
a Department of Earth and Marine Sciences, University of Palermo, CoNISMa, via Archirafi 18, 90123 Palermo, Italy

${ }^{b}$ Department of Environmental Sciences, University of Parma, Parco Area delle Scienze 11/A, 43124 Parma, Italy

c IFREMER, Laboratory of Benthic Ecology, Technopole Brest Iroise BP70 29280 Plouzane, France
}

*: Corresponding author : Francesca Colombo, tel.: + 3909123862874 ; fax: + 390916100278 ; email address : france.colombo@gmail.com

\begin{abstract}
:
Stable isotopes were used to investigate contributions of autochthonous (i.e. benthic: epilithon and macroalgae) and allochthonous (i.e. pelagic: phytoplankton) organic matter sources to the diet of suspension-feeders, grazers and predators associated to small reef-pools (cuvettes) created by the reef-building species Dendropoma petraeum in the north-western coast of Sicily (Italy). Contributions of potential food sources were calculated using Bayesian mixing-models and integrated to a multivariate approach to highlight the diversity of $\mathrm{C}$ and $\mathrm{N}$ pathways within Dendropoma cuvettes. Both pelagic and benthic organic matter sources were exploited by benthic consumers, although clear differences were revealed in the various species depending on their feeding strategy. Three different trophic pathways were identified: one based mainly on phytoplankton, one based mainly on macroalgae and a third one mainly on epilithon. Suspension-feeders seemed to rely mainly on allochthonous organic matter sources, while grazers showed a wider diet spectrum. Predators revealed a high specialization in each of the three food chains and showed a distinct reliance on organic matter originated from benthic or pelagic sources. Stable isotopes evidenced here a marked differentiation of the trophic niche within the cuvette-associated community, which allows minimizing competition in very space-limited conditions.
\end{abstract}

\section{Highlights}

We investigated the organic matter sources use by vermetid reef cuvette community. Stable isotope ratios $\left(\delta^{13} \mathrm{C}, \delta^{15} \mathrm{~N}\right)$ were used to describe the trophic web. Both benthic and pelagic OM sources contributed in different extents. Three different trophic pathways were identified within the cuvette. Predators revealed a high specialization in each of the three trophic pathways.

Keywords: Dendropoma petraeum ; Stable Isotope ; Bayesian Mixing Model ; Trophic Niche ; Intertidal 


\section{Introduction}

Nearshore and shallow coastal areas are characterized by food webs with high level of connectance and by a strong bentho-pelagic coupling (Bode et al., 2006). Generally in these systems, the large variety of primary producers, such as seagrasses, macroalgae, microphytobenthos and phytoplankton makes the identification of food sources exploited by benthic organisms and the detection of the main trophic pathways difficult (Bode et al., 2006; Golléty et al., 2010). In temperate rocky shores communities, macroalgae constitute the most representative vegetation sustaining most primary production (Little et al., 2009). Macroalgae enter the food web mostly via detritic pathways, because of low grazing pressure due to the presence of low digestible components (e.g. polyphenols) (Buchsbaum et al., 1991; Duggins and Eckman, 1997). Moreover, in intertidal rocky shores, herbivores can also largely graze on benthic microalgae (Jenkins and Hartnoll, 2001). Besides this benthic autochthonous production, pelagic allochthonous production (i.e. phytoplankton) actually plays a pivotal trophic role for macrobenthic species (Lefebvre et al., 2009). Thus, both allochthonous and autochthonous organic matter sources support intertidal food webs, even thought their respective roles are affected by local environmental conditions, such as substratum features, hydrodynamic forcing and seasonal variation (Lefebvre et al., 2009; Golléty et al., 2010).

Bioengineer reef building species are known to increase spatial complexity by creating microhabitats, and affecting the local hydro-sedimentary patterns, and ultimately offering numerous spatial niches for a large and often unique diverse associated species (Dubois et al. 2002; Callaway et al., 2010). However, trophic processes within associated reef-building species, such as food partitioning and inter-specific competition, have received little attention so far.

Within rocky intertidal Mediterranean habitats, vermetid reefs are unique and highly diverse biogenic constructions, structurally comparable to coralline reefs in tropical seas (Safriel and BenEliahu, 1991). Indeed, they play a structural role in modifying shape and ecological characteristics of the transitional area between mesolittoral and infralittoral rocky flats, making the habitat more complex and tridimensional. In the Mediterranean Sea, the gastropod Dendropoma petraeum represents the main structural vermetid species (Safriel, 1975). In close association with coralline algae (Safriel 1975; Calvo et al., 1998), it builds reefs, which host a highly diverse community. Dendropoma reefs can be divided into three different morphological zones, from the inshore towards the open sea: the inner edge (terrestrial boundary), the cuvette (pools in the central zone), and the outer edge (sea boundary) (Molinier and Picard, 1953; Chemello and Silenzi, 2011). Each of those zones are fashioned by hydrodynamics features (such as wave exposures) and the reefbuilding activity of the gastropods. The cuvette is the most conspicuous zone, with a high level of habitat heterogeneity and the most diverse associated community (Chemello et al., 1998). Structurally, they are similar to tidal pools in the rocky shore environment (Little et al., 2009). Previous descriptions of benthic assemblages inhabiting these reefs revealed high diversity and species abundance at small scale (i.e. cuvette scale) (Chemello et al., 1998; Badalamanti et al., 1998; Mannino, 1992; Goren and Galil, 2001), but the functional ecology of these unique and complex bioconstructions is still poorly understood (Vizzini et al., 2012).

Stable isotope analyses (SIA) have been used as a powerful tool to describe the organic matter flow and to resolve trophic relationship in coastal ecosystems (e.g. Vizzini and Mazzola, 2006; Bode et al., 2006; Schaal et al., 2010). Classically, the ${ }^{13} \mathrm{C}$ signature patterns are useful to elucidate the origin and pathways of organic matter in food webs, as the primary sources may be isotopically distinct, thus allowing distinctions between pelagic and benthic contributions (France, 1995). The $15 \mathrm{~N}$ signals are used to described food chains lengths and prey-predators relationships (Minagawa and Wada, 1984)

In this study, SIA was used to investigate trophic structure and functioning of vermetid reef intertidal communities and to understand how organic matter sources are exploited by the macrofauna species. In detail, the aims were i) to characterize the food web structure of $D$. 
petraeum reef cuvettes, ii) to investigate the contribution of autochthonous and allochthonous organic matter sources to the consumers" diet, and iii) to examine how food sources are partitioned within small spatial scales (i.e. within cuvettes).

\section{Materials and methods}

\subsection{Study area}

The study was carried out along the north-western coast of Sicily (Italy) in the Marine Protected Area (MPA) "Capo Gallo-Isola delle Femmine". This MPA is divided into three different zones of protection: zone A (integral reserve), zone B (general reserve) and zone $C$ (partial reserve). The intertidal rocky shores and the infralittoral seabed host a number of species and communities worthy of protection for their high ecological value and conservation interest, such as Posidonia oceanica meadows, sciaphilous communities characterized by the soft red macroalgae Corallina elongata and $C$. officinalis, in addition to one of the most extensive vermetid reefs in the Mediterranean (Badalamenti et al., 1992). The sampling area is situated in the zone $\mathrm{B}$ of protection located in the eastern part of the reserve (38 12.754 N, $1317.455 \mathrm{E}$ ).

\subsection{Sample collection}

Macrobenthic organisms and potential food sources, i.e. the autochthonous benthic epilithon (EPI) and macroalgae (MA) and the allochthonous suspended particulate organic matter (SPOM) as a proxy for pelagic phytoplankton, were sampled in May, when primary production reaches maximum values in the Mediterranean. Samples of surface seawater were collected off the reef, so that phytoplankton is not mixed with resuspended material from the reef. EPI, MA and macrobenthos were sampled at low tide in randomly selected reef cuvettes, about $150-200 \mathrm{~cm}$ in size (equivalent spherical diameters), distant from a few meters. EPI was collected in triplicate by scraping the reef surface with blades. The most abundant and frequent reef MA (i.e. Ceramium sp., Cystoseira spp. and Laurencia sp.) (Mannino, 1992) were collected in triplicate by hand.

To investigate the taxonomic groups representing most of the biomass within the cuvettes, sampling focused on the most abundant and representative species typifying the vermetid reef cuvette community, from the basis of several previous investigations (Chemello et al., 1998; Badalamenti et al., 1998; Mannino, 1992). Epifaunal organisms were collected using a diverse set of gears, including scrapers and scalpels for molluscs (bivalves and gastropods), nets for small crustaceans and traps for fishes. Endofaunal species associated to microhabitats within the reefbuilder $D$. petraeum were collected by carefully extracting small portions of reef; particular care was taken to avoid serious damages to the bioconstruction.

\subsection{Laboratory analyses}

Once in the laboratory, SPOM samples were obtained by filtering 2 I of pre-filtered $(200 \mu \mathrm{m})$ seawater onto pre-combusted $\left(450^{\circ} \mathrm{C}, 4 \mathrm{~h}\right)$ Whatman GF/F filters within 2 hours of collection. Epilithon was observed under a stereo-microscope to identify the main components: benthic diatoms and filamentous algae were found to both dominate samples. For technical reasons, the whole sample was analysed for isotopic ratios as separation techniques did not allow to get pure samples. Epibionts were carefully removed from MA samples. EPI, MA and SPOM samples were analysed separately for $\delta^{15} \mathrm{~N}$ and $\delta^{13} \mathrm{C}$. Prior $\delta^{13} \mathrm{C}$ analyses, samples were acidified with drop-bydrop $2 \mathrm{~N} \mathrm{HCl}$ to remove carbonates before drying and grinding (Carabel et al., 2006). For each species of invertebrates and fish, several specimens were pooled, not only to reach the analytical weight in case of small species, but also to limit inter-individual variability. Samples were rinsed with distilled water; muscle tissues were dissected from large individuals (e.g. fishes, large 
crustaceans and molluscs) and whole body was used for small individuals. All samples were dried to constant weight at $60^{\circ} \mathrm{C}$ and ground into a homogeneous powder using mortar and pestle.

Isotopic analyses were performed with an isotope ratio mass spectrometer (ThermoElectron Delta Plus XP) connected to an elemental analyser (ThermoElectron Flash EA 1112). Isotopic values were expressed in conventional $\delta$ unit notation (as parts per mil) in relation to international standards (Peedee Belemnite, for ${ }^{13} \mathrm{C} /{ }^{12} \mathrm{C}$; atmospheric $\mathrm{N}_{2}$ for ${ }^{15} \mathrm{~N} /{ }^{14} \mathrm{~N}$ ), following the formula:

$\delta X=\left[\left(R_{\text {sample }} / R_{\text {standard }}\right)-1\right] \times 10^{3}$, where $X$ is ${ }^{13} \mathrm{C}$ or ${ }^{15} \mathrm{~N}$ and $R$ is the corresponding ${ }^{13} \mathrm{C} /{ }^{12} \mathrm{C}$ or ${ }^{15} \mathrm{~N} /{ }^{14} \mathrm{~N}$ ratio. Analytical precision based on the standard deviation of replicates of internal standards (International Atomic Energy Agency IAEA-NO-3 for $\delta^{15} \mathrm{~N}$ and IAEA-CH-6 for $\delta^{13} \mathrm{C}$ ) was $0.2 \%$ for both $\delta^{13} \mathrm{C}$ and $\delta^{15} \mathrm{~N}$.

Trophic levels were calculated for each consumer following Post $(2002 a)$; the lowest $\delta^{15} \mathrm{~N}$ value in primary consumers was chosen as a baseline.

\subsection{Data analysis}

Statistical significance of differences in stable isotope ratio among OM sources (SPOM, epilithon, and the macroalgae Laurencia sp., Cystoseira spp., Ceramium sp.) was first assessed with nonparametric Kruskal-Wallis tests on ranks and then with post hoc multiple comparison tests (Statistica 8.0 package) when significant. To estimate the proportion of sources contributing to the consumers" diet, we applied a Bayesian mixing model approach, using the software package SIAR (Stable Isotope Analysis in R) (Parnell et al., 2010). When several sources contribute to the diet of an organism, mathematical mixing model can help to estimate the contribution of each endmember to the food web. In this perspective, Bayesian statistics have proven to be of a great help, as they allow models to incorporate variability in organisms and food sources signatures, as well as in trophic fractionation (Parnell et al., 2010). The OM sources considered were EPI and reef MA as autochthonous sources, and SPOM as allochthonous source. Isotopic trophic-step fractionation is no longer considered as a constant value, especially regarding trophic-step enrichment from primary producers to primary consumers, as numerous factors are known to affect discrimination processes in organisms tissues (Martinez Del Rio et al., 2009). Several investigations have provided models as proxy to estimate source-specific trophic enrichment factor (TEF) based on the isotopic signature of the food source (see review in Caut et al., 2009). TEFs were estimated for each of the selected sources based on linear models provided in Caut et al. (2009) for invertebrates, as $\Delta \delta^{13} \mathrm{C}=-0.113 \times \delta^{13} \mathrm{C}_{\text {source }}-1.916$ and $\Delta \delta^{15} \mathrm{~N}=-0.311 \times \delta^{15} \mathrm{~N}_{\text {source }}+4.065$. For consumers exhibiting higher trophic levels (secondary consumers and TL $>3$ ), two TEFs were then considered, the first TEF being calculated using Caut et al. (2009) models and the second TEF in accordance with averaged values reported in the literature $\left(1.0 \%\right.$ for $\delta^{13} \mathrm{C}$ and $3.4 \%$ for $\delta^{15} \mathrm{~N}$ ) (De Niro and Epstein, 1978; Minagawa and Wada, 1984; Post, 2002a), as in higher trophic chain positions TEFs are reported to be much constant (Vander Zanden and Rasmussen, 2001; McCutchan et al., 2003) and cannot be calculated from models since prey signatures are too diverse. As showed in Table 1, TEF for first trophic step was comprised between -0.6 and $+0.5 \%$ for $\Delta \delta^{13} \mathrm{C}$ and +2.0 and $+4.0 \%$ for $\Delta \delta^{15} \mathrm{~N}$, which fall perfectly within the ranges of reviewed estimates of TEFs (ibid.). The standard deviations calculated for TEFs originated from the variability in primary consumers" isotopic signatures.

In order to identify food sources pathways, non-Metric Multidimensional scaling (nMDS) ordination and hierarchical clustering (Euclidean distance, group average mode) were performed on the Bayesian mixing model results. Minimum, maximum (expressed as 95th percentiles) and mean contributions to the consumer diet for each food source were used as factors for each species, to encompass all the variability in the estimation of food sources contributions. Clusters were tested with the similarity profile (Simprof) procedure described in Clarke and Gorley (2006). All the species diets (along with uncertainties) were permutated and compared with what expected under a simple null hypothesis of no differences in primary consumer"s contributions to diets. This 
procedure hence meaningfully grouped all species that rely on the same basal sources, regardless their feeding mode or trophic level.

\section{Results}

\section{1. $\delta^{13} \mathrm{C}$ and $\delta^{15} \mathrm{~N}$ of organic matter sources and consumers}

Isotopic values of organic matter sources exhibited wide ranges for both carbon and nitrogen: $\delta^{15} \mathrm{~N}$ ranged from $0.3 \pm 0.2 \%$ for epilithon to $6.7 \pm 1.8 \%$ for Laurencia sp., while $\delta^{13} \mathrm{C}$ values varied from $-21.8 \pm 0.6 \%$ for SPOM to $-11.9 \pm 0.3 \%$ for epilithon (Table 2). Overall significant differences between organic matter sources were observed for both $\delta^{13} \mathrm{C}(p<0.001)$ and $\delta^{15} \mathrm{~N}(p<0.001)$. However post-hoc multiple comparisons showed that no significant differences were found between macroalgal species, hereafter pooled as a unique source called macroalgae (MA).

Consumers" isotopic signatures also exhibited large isotopic carbon and nitrogen ranges (Table 2). The lowest $\delta^{15} \mathrm{~N}$ values were for sea sponges Chondrillidae $(6.0 \pm 0.4 \%$ ), hence used as baseline to calculate trophic levels of other species. Blenniidae finfishes, and especially Aidablennius sphynx $\left(11.9 \pm 0.6 \%\right.$ ) exhibited the highest $\delta^{15} \mathrm{~N}$ values $(11.9 \pm 0.6 \%$ ). Estimates of trophic levels allowed the distinction between primary consumers $(2<\mathrm{TL}<3)$ and secondary consumers $(\mathrm{TL}>3)$, as reported in Fig. 1, which matched the feeding mode retrieved from the literature (Table 2). Carbon signatures of consumers varied markedly, mainly for primary consumers that are well discriminated on the $\delta^{13} \mathrm{C}$ axis, with no overlap. Organisms" signatures spanned from the most depleted values of filter-feeders (from -19.2 to $-18.1 \%$ ) to more enriched values of grazers (from -17 to $-13.7 \%$ ). Secondary consumers exhibited a slight narrower carbon range than primary consumers (Fig. 1).

\subsection{Mixing model output}

Bayesian mixing model outcomes showed a high variability in the relative contributions of the three OM sources (EPI, MA and SPOM) to the consumers" diet (Table 2), as most of the species signatures fell close to the barycentre of the isotopic space defined by the 3 potential food sources; the ranges of possible contributions were expressed as $95^{\text {th }}$ percentiles interval. Overall, EPI percentage contributions exhibited the lowest values for $A$. sphynx, ranging from 0.0 to $21.4 \%$, while the highest values for Patella ulyssiponensis, ranging from $36.7 \%$ to $76.3 \%$; MA lowest proportion in diet was for Cardita calyculata (from 0.0 to $37.4 \%$ ), whereas the highest was for Gammarus sp. (from $19.0 \%$ to $86.6 \%$ ); SPOM contribution showed the widest range of variation, displaying proportion values from 0.0 to $17.5 \%$ for Patella caerulea, while from $38.6 \%$ to $88.9 \%$ for the Nereididae Perinereis cultrifera (Table 2).

Overall, three groups of consumers were identified using cluster and nMDS ordination (Fig. 2). As ordination was performed on the Bayesian mixing model results, within each group, species depend on the same basal sources and hence belong to the same trophic pathway. Simprof procedure showed that the three clusters were significantly discriminated $(p<0.01)$. The group $A$ is the larger one and relied largely on SPOM. It included all the filter-feeders, three carnivores/omnivores (i.e. the Eunicidae Lysidice ninetta, the Nereididae P. cultrifera and Lipophrys canevae). The group $\mathrm{B}$ had an intermediate size and was characterized by a larger contribution of MA as basal source. It included grazers (Gammarus sp., Hyale sp., Patella rustica, Parablennius sanguinolentus) and carnivores/omnivores ( $A$. sphynx and Coryphoblennius galerita). The group $C$ was the smallest one and clustered $P$. caerulea and $P$. ulyssiponensis, together with Phascolosoma granulatum and Salaria pavo. Those species mainly rely on EPI, with the exception of $P$. cerulea, showing a slightly higher mean contribution of MA. 


\section{Discussion}

\subsection{Contribution of organic matter sources to food web pathways}

Vermetid reef cuvettes represent an intertidal complex system of pools featured by rich faunal abundance and diversity, as well as rich macroalgae and epilithic community. The spatial complexity of the reef offers large surfaces for macroalgae and epilithon to grow, making those sources of primary importance in the contribution of the diet to local diversity. Allochthonous organic matter input originating from the open sea as phytoplankton (SPOM), enter the $D$. petraeum cuvettes in an uneven manner and mainly through wave action. Autochthonous and allochthonous organic matter sources are isotopically distinguishable for both carbon and nitrogen. SPOM showed a lower proportion of the heavy carbon isotope than the autochthonous OM sources, which is consistent with the prevalence of phytoplanktonic components, typically depleted in comparison with benthic organic matter (France, 1995). The SPOM isotopic signature matches literature data (e.g. Harmelin-Vivien et al., 2008; Lefebvre et al., 2009). Macroalgae had a much depleted $\delta^{13} \mathrm{C}$ signal than phytoplankton, while $\delta^{15} \mathrm{~N}$ remained quite similar. All investigated macroalgae species had non-significantly different signatures and were considered as a unique pool of organic matter. As a result, if some specialization between macroalgae grazers occurs, SIA did not allow discrimination within the community. Epilithon showed an isotopic signature highly enriched in ${ }^{13} \mathrm{C}$ and depleted in ${ }^{15} \mathrm{~N}$ compared to other potential food sources. Such a signature is due to the prevalence of filamentous cyanobacteria (see Vizzini et al., 2012 and references therein). Cyanobacteria, while rarely investigated in isotopic studies - mostly for technical reasons - commonly co-occur with pelagic or benthic microalgae and are suspected to play a significant role as a food resource in sandy sediments (Evrard et al., 2010). However, despite the ubiquitous distribution, their trophic role is still poorly described in rocky shores and their contributions, when evidenced, remain sporadic in time or minor in terms of contribution (Golléty et al., 2010; Schaal et al., 2010). However, this investigation clearly evidenced the role of cyanobacteria in the food web cuvettes of $D$. petraeum reefs.

The carbon isotopic signatures of the cuvette species spanned approximately over the same $\delta^{13} \mathrm{C}$ range as the food sources (ca. 7\%o). This indicates that the whole trophic niche of the cuvette space (as defined by the diversity of the food sources) was exploited, hence minimizing interspecific competition for food. Because food sources are isotopically easily discriminated, the results of the mixing models offered here trustworthy estimates of species diets and allowed us to better understand the general food web structure within the cuvette habitat. Multivariate analysis revealed the presence of 3 main pathways of organic matter sources, embracing groups of species sharing the same basal sources.

The first trophic pathway had phytoplankton as main basal source, and includes species (identified as group $\mathrm{A}$ ) with a mean estimated contribution of SPOM of $55 \%$ (mean $\min =31 \%$; mean $\max =$ $75 \%$ ). Species identified from the literature as suspension-feeders are represented here with the bivalves $C$. calyculata and Mytilaster minimus, as well as the sea-sponges (Chondrillidae). The reef-builder $D$. petraeum also mainly relied on phytoplankton, as previously showed (Vizzini et al., 2012). Even if all the filter-feeders clustered together, they showed differences in the sources contribution, meaning that their trophic niche did not completely overlap, as reported for filter feeders in other studies (Dubois et al., 2007a, 2007b; Schaal et al., 2010). This pathway also includes polychaete species of the families Eunicidae and Nereididae: even if they are often reported as carnivores/omnivores, $L$. ninetta showed trophic level lower than the other predators, whereas $P$. cultrifera exhibited here a predatory behaviour by targeting species from this group $A$ (although the large $\delta^{15} \mathrm{~N}$ range suggests that it feeds on various trophic level). It is likely that Nereididae prey upon the most abundant species, namely $D$. petraeum, as predatory polychaetes belonging to this family are often reported in biogenic structures where they prey in tubes from the reefs builder (Dubois et al., 2002). In exhaustive investigations of coastal benthic community, Nereididae also exhibit high nitrogen values (Grall et al., 2006; Dubois et al., 2007a, Schaal et al., 2010). The Blenniidae $L$. canevae has a similar trophic level to $P$. cultrifera, although in the 
literature the dominance of algae in gut contents is reported (Velasco et al., 2010). This study showed that they may also prey upon $D$. petraeum. Indeed, while they cannot reach the entire mollusc within its tube, they actually "graze" the head from $D$. petraeum filtering individuals. The very close species Lipophrys pholis was also reported to prey on reef-builder Sabellaria alveolata heads (Dubois et al., 2002).

The second pathway was based on macroalgae, being composed of species (group B) that relied mainly on macroalgae as basal sources (on average 48\%; mean $\min =16 \%$; mean $\max =80 \%$ ). At the bottom of this pathway, the gastropod $P$. rustica and two amphipod species (Gammarus sp. and Hyale sp.), as well as the finfish $P$. sanguinolentus where all identified as grazers from the literature (Hawkins et al., 1989; Ruffo, 1998, Velasco et al., 2010). However, the mollusc $P$. rustica showed a higher $\delta^{13} \mathrm{C}$ signature than amphipods or $P$. sanguinolentus, suggesting either the grazing on different macroalgae or a larger contribution of epilithon. At the top of this pathway, two carnivorous Blenniidae species ( $A$. sphynx and $C$. galerita) are targeting amphipods as the main component of their diet.

The third food pathway included species (group C) mainly based on epilithon, which yielded an average contribution of $42 \%$ (mean $\min =30 \%$; mean $\max =62 \%$ ). This group is composed of the two gastropods, Patella caerulea and $P$. ulyssiponensis, known to scrape the reef surface with their radula (Hawkins et al., 1989). The sipunculid $P$. granulatum belongs to this pathway, but exhibited a much higher $\delta^{15} \mathrm{~N}$ value than the Patellidae species. Little is known on sipunculids" diet, but they are mainly considered as deposit-feeders (Murina, 1984). This species is found in the crevices and in empty $D$. petraeum tubes, where it scrapes off food from the substratum for epilithon and macroalgae detritus: it is likely that it also behaves as a scavenger during its borrowing activity, feeding on died organisms, hence explaining its high $\delta^{15} \mathrm{~N}$ value. S. pavo is a Blenniidae species living in crevices and this study shows that it is likely to prey on Patellidae species.

The clustering of species into three different trophic pathways is based on the result of similarities in food sources contributions in species diets estimated with Bayesian statistics. While this approach led here to three obvious - statistically distinct - clusters, one should also consider that species are trophically plastic. This MDS approach produces here hard clustering, because a clear-cut decision for each object (species) is made. Further applications of this approach need to pay special attention to species at the edges of the clusters, hence considering they may belong to several clusters. In this perspective, fuzzy clustering method allows for some ambiguity in the data, which often occurs in practice, especially for trophic behaviour.

\subsection{Structure and functional diversity within cuvette food web}

Isotopic data on the main species representing most of the diversity and the biomass of the benthic assemblage associated to the cuvette of $D$. petraeum reefs revealed that both allochthonous and autochthonous food sources contribute to the food web. Cuvettes are morphological depressions created by vermetid biogenic reefs and are in many ways similar to tidal pools on rocky shores. Intertidal tides pools are stressful environments for benthic organisms, with immersion and emersion periods bringing allochthonous food (phytoplankton) (Little et al., 2009). This study showed that within the cuvette food web, the whole trophic niche is exploited by species inhabiting the cuvettes: indeed, we showed here that the number of species is evenly distributed between allochthonous ( $45 \%$ of species) and autochthonous (55\% of species) food sources. This could contribute to regulate primary production within the cuvettes and to minimize intra- and interspecific food competition in a stressful environment subject to short-term changes. By closely looking at the grazers trophic group, for example, it is worth noticing an even split between species focusing mainly on macroalgae and species focusing on epilithic microalgae. Even within the Patellidae, one of the most abundant and diverse group in rocky shores (Little et al., 2009), mixing models revealed inter-specific differences in their diets. Calculation of the trophic levels also revealed an equal distribution of predators between each food pathway. While fish species (i.e. L. canevae) and polychaetes (i.e. P. cultrifera) feed on suspension-feeders, other fishes 
(i.e. A. sphinx and C. galerita) prey on macroalgae grazers and S. pavo prey on epilithon grazers. These results are supported by previous investigations of gut contents of Blenniidae from rocky pools, revealing high degree of trophic specialization (Velasco et al., 2010). Interestingly, the Eunicidae species did not exhibit a predatory behaviour, as suggested from the literature (Fauchald and Jumars, 1979) and hence limits the trophic competition with other polychaete predators (e.g. Nereididae species),as previously showed in soft sediment between Eunicidae and Glyceridae species (Dubois et al., 2007a). The diversity in predator trophic niches can reduce the top-down effect in the community organization (e.g. Estes et al., 2001) and we hypothesized here that the diversity in top-down pressures could contribute to the stability and the resilience of cuvettes food web.

Variations in $\delta^{15} \mathrm{~N}$ ranges give an estimate of the length of the food chain, and provide a proxy of the complexity in trophic interactions (Post, 2002b). Autochthonous and allochthonous food pathways exhibited very similar food chain lengths and all the predators exhibited very similar $\delta^{15} \mathrm{~N}$ signatures. This pattern leads to a wide range in $\delta^{13} \mathrm{C}$ at the top of the food chain. This isotopic space pattern is uncommon (the isotopic space is actually not pyramidal-shaped), because rocky shore communities classically revealed that top predators all prey upon all species, coupling the diverse pathways, hence showing a narrower $\delta^{13} \mathrm{C}$ range (Gollety et al., 2010). Conversely predators investigated here revealed a high level of specialization in each of the three food chains, showing that even at small spatial scale (meter-scale), high specialisation of predators leads to the exploitation of the whole trophic niche, which allows minimizing competition.

\section{Acknowledgments}

We are grateful to R. Chemello for sharing his knowledge and for his precious suggestions, A. Savona for field assistance, A.E. Aleo for help with laboratory analyses. The authors are grateful to Dr. C.G. Gelpi (Louisiana State University) who corrected and edited the English grammar. This study was funded by the Università di Palermo and Ministero dell"Istruzione, dell'Università e della Ricerca.

\section{References}

Avila, S.P., 2003. The littoral molluscs (Gastropoda, Bivalvia and Polyplacophora) of Sao Vicente, Capelas (Sao Miguel Island, Azores): ecology and biological associations to algae. Iberus 21, $1-23$.

Badalamenti, F., Chemello, R., D"Anna, G., Riggio, S., 1998. Diversity of the Polychaete assemblage in the hard bottom mediolittoral along the north-western sicilian coast: the role played by the vermetid biocostruction. $1^{\circ}$ Convegno Nazionale delle Scienze del Mare "Diversità e Cambiamento" Abstract 14.

Badalamenti, F., Chemello, R., Gristina, M., Riggio, S., Toccaceli M., 1992. Caratterizzazione delle piattaforme a molluschi vermetidi nella costa tra Capo Gallo ed Isola delle Femmine (PA): area proposta come riserva naturale marina. Oebalia 17, 547-549.

Barash, A., Zenziper Z., 1985. Structural and biological adaptation of Vermetidae (Gastropoda). Bollettino Malacologico Milano 21, 145-176.

Bell, J.J., 2008. The functional roles of marine sponges. Estuarine, Coastal and Shelf Science 79, 341-353.

Bode, A., Alvarez-Ossorio, M.T., Vrela, M., 2006. Phytoplankton and macrophyte contributions to littoral food webs in the galician upwelling estimated from stable isotopes. Marine Ecology Progress Series 318, 89-102.

Buchsbaum, R., Valiela, I., Swain, T., Dzierzeski, M., Allen, S., 1991. Available and refractory nitrogen in detritus of coastal vascular plants and macroalgae. Marine Ecology Progress Series 72, 131-143. 
Callaway, R., Desroy, N., Dubois, S.F., Fournier, J., Frost, M., Godet, L., Hendrick, V.J., Rabaut, M., 2010. Ephemeral bio-engineers or reef-building polychaetes: how stable are aggregations of the tube worm Lanice conchilega (Pallas, 1766)? Integrative and Comparative Biology 50, 237-250.

Calvo, M., Templado, J., Penchaszadeh, P.E., 1998. Reproductive biology of the Gregarious Mediterranean vermetid gastropod Dendropoma petraeum. Journal of the Marine Biological Association of the United Kingdom 78, 525-549.

Carabel, S., Godínez-Domínguez, E., Verísimo, P., Fernández, L., Freire, J., 2006. An assessment of sample processing methods for stable isotope analyses of marine food webs. Journal of Experimental Marine Biology and Ecology 336, 254-261.

Caut, S., Angulo, E., Courchamp, F., 2009. Variation in discrimination factors $\left(\Delta^{15} \mathrm{~N}\right.$ and $\left.\Delta^{13} \mathrm{C}\right)$ : the effect of diet isotopic values and applications for diet reconstruction. Journal of Applied Ecology 46, 443-453.

Chemello, R., Ciuna, I., Pandolfo, A., Riggio, S., 1998. Molluscan assemblages associated with intertidal vermetid formations: a morpho-functional approach. Bollettino Malacologico Roma 33, 105-114.

Chemello, R., Silenzi S., 2011. Vermetid reefs in the Mediterranean Sea as archives of sea-level and surface temperature changes. Chemistry and Ecology 27, 121-127.

Clarke, K.R., Gorley, R.N., 2006. Primer Ver. 6 User Manual/Tutorial. Primer-E, Plymouth.

De Niro, M.J., Epstein, S., 1978. Influence of diet on the distribution of carbon isotopes in animals. Geochimica et Cosmochimica Acta 42, 495-506.

Dubois, S., Marin-léal, J.C., Ropert, M., Lefebvre, S., 2007a. Effects of oyster farming on macrofaunal assemblages associated with Lanice conchilega tubeworm populations: A trophic analysis using natural stable isotopes. Aquaculture 271, 336-349.

Dubois, S., Orvain, F., Marin-léal, J. C., Ropert, M., and Lefebvre, S., 2007b. Small-scale spatial variability of food partitioning between cultivated oysters and associated suspension-feeding species, as revealed by stable isotopes. Marine Ecology Progress Series 336, 151-160.

Dubois, S., Retiere, C., Olivier, F., 2002. Biodiversity associated with Sabellaria alveolata (Polychaeta: Sabellariidae) reefs: effects of human disturbances. Journal of the Marine Biological Association of the United Kingdom 82, 817-826.

Duggins, D.O., Eckman, J.E., 1997. Is kelp detritus a good food for suspension feeders? Effects of kelp species, age and secondary metabolites. Marine Biology 128, 489-49.

Estes, J., Crooks, K., Holt, R., 2001. Ecological role of predators, Encyclopedia of Biodiversity (Vol 4). Academic Press, pp. 857-878.

Evrard, V., Soetaert, K., Heip, C.H.R., Huettel, M., Xenopoulos, M.A., Middelburg, J.J., 2010. Carbon and nitrogen flows through the benthic food web of a photic subtidal sandy sediment. Marine Ecology Progress Series 416, 1-16.

Fauchald K., Jumars P.A., 1979. The diet of worms: a study of polychaete feeding guilds. Oceanography and Marine Biology: An Annual Review 17, 193-284.

France, R.L., 1995. Carbon-13 enrichment in benthic compared to planktonic algae: food web implications. Marine Ecology Progress Series 124, 307-312.

Goldschmid, A., Kotrschal, A.K., Wirtz, P., 1984. Food and gut length of 14 adriatic blenniid fish (Blenniidae; Percomorpha; Teleostei). Zoologischer Anzeiger, Jena 213,145-150.

Golléty, C., Riera, P., Davoult, D., 2010. Complexity of the food web structure of the Ascophyllum nodosum zone evidenced by a $\delta^{13} \mathrm{C}$ and $\delta^{15} \mathrm{~N}$ study. Journal of Sea Research 64, 304-312.

Goren, M., Galil, B.S., 2001. Fish biodiversity in the vermetid reef of Shiqmona (Israel). Marine Ecology 22, 369-378.

Grall, J., Le Loc'h, F., Guyonnet, B., Riera, P., 2006. Community structure and food web based on stable isotopes $\left(\delta^{15} \mathrm{~N}\right.$ and $\left.\delta^{13} \mathrm{C}\right)$ analysis of a North Eastern Atlantic maerl bed. Journal of Experimental Marine Biology and Ecology 338, 1-15.

Harmelin-Vivien, M., Loizeau, V., Mellon, C., Beker, B., Arlhac, D., Bodiguel, X., Ferraton, F., Hermand, R,. Philippon, X., Salen-Picard, C., 2008. Comparison of C and N stable isotope ratios between surface particulate organic matter and microphytoplankton in the Gulf of Lions (NW Mediterranean). Continental Shelf Research 28, 1911-1919. 
Hawkins, S.J., Watson, D.C., Hill, A.S., Harding, S.P., Kyriakides, M.A., Hutchinson, S., Norton, T.A., 1989. A comparison of feeding mechanisms in microphagous, herbivorous, intertidal, prosobranchs in relation to resource partitioning. Journal of Molluscan Studies 55, 151-165.

Jenkins, S.R., Hartnoll, R.G., 2001. Food supply, grazing activity and growth rate in the limpet Patella vulgata L.: a comparison between exposed and sheltered shores. Journal of Experimental Marine Biology and Ecology 258, 123-139.

Lefebvre, S., Leal, J.C.M., Dubois, S., Orvain, F., Blin, J.L., Bataille, M.P., Ourry, A., Galois, R., 2009. Seasonal dynamics of trophic relationships among co-occurring suspension-feeders in two shellfish culture dominated ecosystems. Estuarine Coastal and Shelf Science 82, 415425.

Little, C., Williams, G.A., Trowbridge, C.D., 2009. The biology of rocky shores. 2nd ed. Oxford University Press, New York.

Mannino, A.M., 1992. Studio fitosociologico della vegetazione mesolitorale a Lithophyllum lichenoides PHILIPPI (Rhodophyceae, Corallinales). Naturalista siciliano, Palermo IV, 16, 3-25

Martinez Del Rio, C., Wolf, N., Carleton, S.A., Gannes, L.Z., 2009. Isotopic ecology ten years after a call for more laboratory experiments. Biological Reviews 84, 91-111.

McCutchan, J.H. Jr, Lewis, W.M. Jr, Kendall, C., McGrath, C.C., 2003. Variation in trophic shift for stable isotope ratios of carbon, nitrogen, and sulphur. Oikos 102, 378-390.

Minagawa, M., Wada, E., 1984. Stepwise enrichment of ${ }^{15} \mathrm{~N}$ along food chains: further evidence and the relation between ${ }^{15} \mathrm{~N}$ and animal age. Geochimica Cosmochimica Acta 48, 1135-1140.

Molinier, R., Picard, J., 1953. Notes biologiques a propos d"un voyage d"étude sur les cotes de Sicile. Annales de l'Institut Océanographique de Monaco 28, 163-188.

Murina, G.V., 1984. Ecology of Sipuncula. Marine Ecology Progress Series 17, 1-7.

Owens, N., 1987. Natural variations in ${ }^{15} \mathrm{~N}$ in the marine environment. Advances in Marine Biology 24, 389-451.

Parnell, A.C., Inger, R., Bearhop, S., Jackson, A.L., 2010. Source partitioning using stable isotopes: coping with too much variation. PLoS ONE 5, e9672.

Post, D.M., 2002a. Using stable isotopes to estimate trophic position: models, methods, and assumptions. Ecology 83, 703-718.

Post, D.M., 2002b. The long and short of food-chain length. Trends in Ecology and Evolution 17, 269-277.

Ruffo, S., 1998. The Amphipoda of the Mediterranean, Part 4. Mémoires de I"Institut Océanographique de Monaco 13, 815-959.

Safriel, U.N., 1975. The role of vermetid Gastropods in the formation of Mediterranean and Atlantic reefs. Oecologia 20, 85-101.

Safriel, U.N., Ben-Eliahu, M.N., 1991. The influence of habitat structure and environmental stability on the species diversity of polychaetes in vermetid reefs. In: Bell, S.S., McCoy, E.D., Mushinsky, H.R. (Eds), Habitat Structure - The Physical Arrangement of Objects in Space, Chapman and Hall, London, pp. 349-372.

Schaal, G., Riera, P., Leroux, C. Grall, J., 2010. A seasonal stable isotope survey of the food web associated to a peri-urban rocky shore. Marine Biology 157, 283-294.

Vander Zanden, M.J., Rasmussen, J.B., 2001. Variation in delta N-15 and delta C-13 trophic fractionation: Implications for aquatic food web studies. Limnology and Oceanography 46, 2061-2066.

Velasco, E.M., Gómez-Cama, M.C., Hernando, J.A. Soriguer, M.C. 2010. Trophic relationships in an intertidal rockpool fish assemblage in the gulf of Cádiz (NE Atlantic). Journal of Marine Systems 80, 248-252.

Vizzini, S., Colombo F., Costa, V., Mazzola, A., 2012. Contribution of planktonic and benthic food sources to the diet of the reef-forming vermetid gastropod Dendropoma petraeum in the western Mediterranean. Estuarine, Coastal and Shelf Science 96, 262-267.

Vizzini, S., Mazzola, A., 2006. Sources and transfer of organic matter in food webs of a Mediterranean coastal environment: evidence for spatial variability. Estuarine, Coastal and Shelf Science 66, 459-467. 


\section{Tables}

Table 1. Estimates of Trophic Enrichment Factors using food source signatures, after models for invertebrates developed by Caut et al. (2009) for $\Delta \delta^{13} \mathrm{C}=-0.113 \times \delta^{13} \mathrm{C}_{\text {Source }}-1.916$ and $\Delta \delta^{15} \mathrm{~N}=$ $-0.311 \times \delta^{15} \mathrm{~N}_{\text {Source }}+4.065$.

\begin{tabular}{|l|c|c|c|c|}
\hline Source & Mean $\delta^{13} \mathrm{C}$ TEF & sd & Mean $\delta^{15} \mathrm{~N}$ TEF & sd \\
\hline EPI & -0.6 & 0.0 & 4.0 & 0.1 \\
\hline MA & -0.2 & 0.2 & 2.2 & 0.4 \\
\hline SPOM & 0.5 & 0.1 & 2.0 & 0.3 \\
\hline
\end{tabular}


Table 2. $\delta^{13} \mathrm{C}$ and $\delta^{15} \mathrm{~N}$ mean values (\%o), trophic level (TL) and percentage contribution of organic matter (OM) sources to the diet (mixing model output) of consumers. The feeding mode of consumers based on literature data is provided. N: number of samples; sd: standard deviation; low: lower $95^{\text {th }}$ percentile proportion; high: higher $95^{\text {th }}$ percentile proportion.

\begin{tabular}{|c|c|c|c|c|c|c|c|c|c|c|c|c|c|c|c|c|c|c|}
\hline \multirow[t]{2}{*}{ OM sources and consumers } & \multirow[t]{2}{*}{ Feeding mode } & \multirow[t]{2}{*}{ Code } & \multirow[t]{2}{*}{$\mathbf{N}$} & \multicolumn{2}{|c|}{$\delta^{13} \mathrm{C}$} & \multicolumn{2}{|c|}{$\delta^{15} \mathrm{~N}$} & \multicolumn{2}{|c|}{ TL } & \multicolumn{3}{|c|}{$\%$ EPI } & \multicolumn{3}{|c|}{$\%$ MA } & \multicolumn{3}{|c|}{$\%$ SPOM } \\
\hline & & & & mean & sd & mean & sd & mean & sd & low & high & mean & low & high & mean & low & high & mean \\
\hline \multicolumn{19}{|l|}{ Autochthonous OM sources } \\
\hline Epilithon & & & 9 & -11.9 & 0.3 & 0.3 & 0.2 & & & & & & & & & & & \\
\hline Ceramium sp. & & & 9 & -15.8 & 1.3 & 5.5 & 0.4 & & & & & & & & & & & \\
\hline Cystoseira spp. & & & 9 & -15.5 & 1.1 & 5.8 & 0.3 & & & & & & & & & & & \\
\hline Laurencia sp. & & & 9 & -14.3 & 1.2 & 6.7 & 1.8 & & & & & & & & & & & \\
\hline \multicolumn{19}{|l|}{ Allochthonous OM sources } \\
\hline SPOM & & & 6 & -21.8 & 0.6 & 6.5 & 0.9 & & & & & & & & & & & \\
\hline \multicolumn{19}{|l|}{ Consumers } \\
\hline \multicolumn{19}{|l|}{ Porifera } \\
\hline Chondrillidae & Filter feeder $^{a}$ & 1 & 3 & -18.4 & 0.3 & 6.0 & 0.4 & 2.0 & 0.1 & 2.1 & 59.1 & 29.8 & 0.0 & 45.9 & 19.5 & 17.5 & 73.1 & 50.7 \\
\hline \multicolumn{19}{|l|}{ Mollusca } \\
\hline Cardita calyculata & Filter feeder $^{\mathbf{b}}$ & 2 & 5 & -18.7 & 0.5 & 6.2 & 0.6 & 2.1 & 0.2 & 1.3 & 46.0 & 24.3 & 0.0 & 37.4 & 13.9 & 40.8 & 76.0 & 61.8 \\
\hline Dendropoma petraeum & Filter feeder $^{c}$ & 3 & 9 & -18.1 & 0.2 & 7.9 & 0.7 & 2.5 & 0.2 & 7.6 & 29.6 & 18.7 & 8.8 & 42.7 & 25.7 & 47.5 & 63.2 & 55.6 \\
\hline Mytilaster minimus & Filter feeder $^{d}$ & 4 & 3 & -18.4 & 0.4 & 7.9 & 0.4 & 2.6 & 0.1 & 0.2 & 29.1 & 14.8 & 2.2 & 52.9 & 29.4 & 38.0 & 72.9 & 55.8 \\
\hline Patella caerulea & Grazer $^{\mathrm{e}}$ & 5 & 5 & -13.7 & 0.8 & 6.7 & 0.6 & 2.2 & 0.2 & 30.4 & 61.3 & 45.0 & 30.9 & 66.6 & 49.1 & 0.0 & 17.5 & 5.8 \\
\hline Patella rustica & Grazer $^{\mathrm{e}}$ & 6 & 3 & -14.5 & 1.2 & 7.6 & 0.1 & 2.5 & 0.0 & 5.3 & 51.7 & 29.3 & 13.3 & 81.2 & 46.6 & 0.0 & 51.5 & 24.1 \\
\hline Patella ulyssiponensis & Grazer $^{e}$ & 7 & 3 & -14.3 & 0.1 & 6.1 & 1.0 & 2.0 & 0.2 & 36.7 & 76.3 & 55.5 & 3.4 & 55.5 & 32.9 & 0.0 & 22.5 & 11.6 \\
\hline \multicolumn{19}{|l|}{ Crustacea, Amphipoda } \\
\hline Gammarus sp. & Grazer $^{f}$ & 8 & 4 & -16.3 & 1.0 & 8.3 & 0.8 & 2.7 & 0.2 & 0.0 & 38.7 & 17.3 & 19.0 & 86.6 & 53.1 & 7.8 & 51.2 & 29.6 \\
\hline Hyale sp. & Grazer $^{f}$ & 9 & 4 & -17.0 & 0.7 & 8.0 & 0.7 & 2.6 & 0.2 & 0.8 & 34.1 & 18.0 & 16.6 & 70.6 & 43.9 & 22.1 & 53.5 & 38.1 \\
\hline \multicolumn{19}{|l|}{ Anellida, Polychaeta } \\
\hline Lysidice ninetta & Carnivorous/omnivorous $^{\mathrm{g}}$ & 10 & 4 & -16.9 & 1.4 & 9.6 & 0.9 & 3.1 & 0.3 & 10.2 & 58.8 & 36.8 & 0.0 & 48.0 & 20.9 & 13.8 & 66.4 & 42.3 \\
\hline Perinereis cultrifera & Carnivorous/omnivorous $^{\mathrm{g}}$ & 11 & 3 & -18.6 & 0.5 & 11.4 & 2.1 & 3.6 & 0.6 & 0.0 & 28.1 & 11.8 & 0.0 & 44.3 & 19.7 & 38.6 & 88.9 & 68.6 \\
\hline Sabella sp. & Filter feeder ${ }^{\mathbf{g}}$ & 12 & 3 & -19.2 & 0.8 & 7.0 & 0.0 & 2.3 & 0.0 & 4.3 & 46.3 & 27.0 & 0.0 & 47.6 & 22.1 & 21.4 & 79.5 & 50.9 \\
\hline \multicolumn{19}{|l|}{ Sipuncula } \\
\hline Phascolosoma granulatum & Omnivorous $^{h}$ & 13 & 6 & -14.7 & 0.1 & 10.3 & 0.4 & 3.3 & 0.1 & 29.7 & 52.7 & 40.8 & 14.4 & 49.3 & 32.3 & 18.3 & 35.0 & 26.9 \\
\hline \multicolumn{19}{|l|}{ Fish } \\
\hline Aidablennius sphynx & Carnivorous/omnivorous $^{i}$ & 14 & 5 & -16.5 & 0.9 & 11.9 & 0.6 & 3.7 & 0.2 & 0.0 & 21.4 & 8.8 & 26.2 & 70.1 & 48.6 & 27.4 & 57.8 & 42.5 \\
\hline Coryphoblennius galerita & Carnivorous/omnivorous ${ }^{\prime}$ & 15 & 3 & -15.2 & 0.6 & 11.6 & 0.3 & 3.6 & 0.1 & 0.6 & 42.8 & 21.6 & 14.8 & 81.3 & 47.3 & 8.6 & 51.7 & 31.1 \\
\hline Lipophrys canevae & Omnivorous ${ }^{i, 1}$ & 16 & 3 & -17.1 & 0.6 & 11.6 & 0.7 & 3.6 & 0.2 & 0.0 & 29.4 & 13.1 & 6.2 & 61.5 & 36.5 & 32.1 & 68.5 & 50.5 \\
\hline Parablennius sanguinolentus & Grazer ${ }^{\prime}$ & 17 & 3 & -16.2 & 0.5 & 8.5 & 0.5 & 2.7 & 0.1 & 0.0 & 46.8 & 23.5 & 10.2 & 82.6 & 46.1 & 7.0 & 50.0 & 30.5 \\
\hline Salaria pavo & Carnivorous/omnivorous ${ }^{\mathrm{i}, \mathrm{l}}$ & 18 & 3 & -14.6 & 0.6 & 10.2 & 0.6 & 3.2 & 0.2 & 20.9 & 56.4 & 38.9 & 7.1 & 63.8 & 36.4 & 6.0 & 42.9 & 24.7 \\
\hline
\end{tabular}

a Bell, 2008; b Avila, 2003; c Barash and Zenziper, 1985; d Safriel and Sasson-Frostig, 1988; e Haw kins et al., 1989; f Ruffo, 1998; $\mathbf{g}$ Fauchald and Jumars, 1979; h Murina, 1984; i Goldschmid et al., 1984; I Velasco et al., 2010. 


\section{Figures}

Figure. 1. $\delta^{13} \mathrm{C}$ and $\delta^{15} \mathrm{~N}$ mean values (\%o) and standard deviations for organic matter sources ( $\square$ ), invertebrates $(\odot)$ and fish $(\Delta)$ in the study area. EPI: epilithon; MA: macroalgae; SPOM: suspended particulate organic matter; consumers are coded in Table 1. Shadowed grey vertical bars represent the $\delta^{15} \mathrm{~N}$ encompassed by primary consumers (PC) and secondary consumers (SC) according to calculated TL.

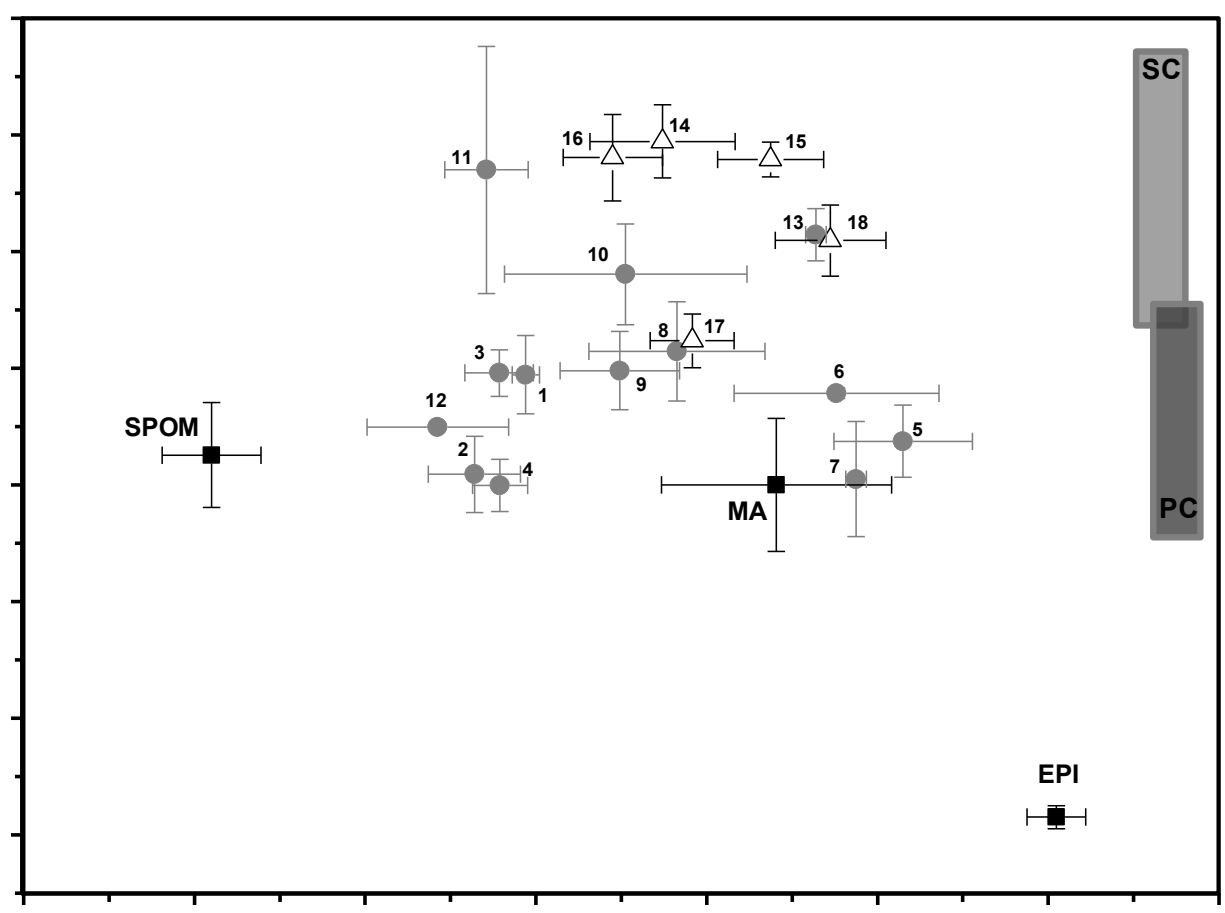


Figure. 2. Dendrogram of hierarchical cluster analysis (a) and non metric multidimensional scaling (nMDS) ordination (b) of similarity matrix (Euclidian distances) on percentage contributions of organic matter sources to the consumers diets (lower 95th percentile, higher 95th percentile and mean value). Significant clusters (A, B and C) corresponding to trophic pathways were tested using the Simprof procedure. Ff: filter feeders; Gr: grazers; C/O: carnivores/omnivores. Consumers are coded in Table 1.

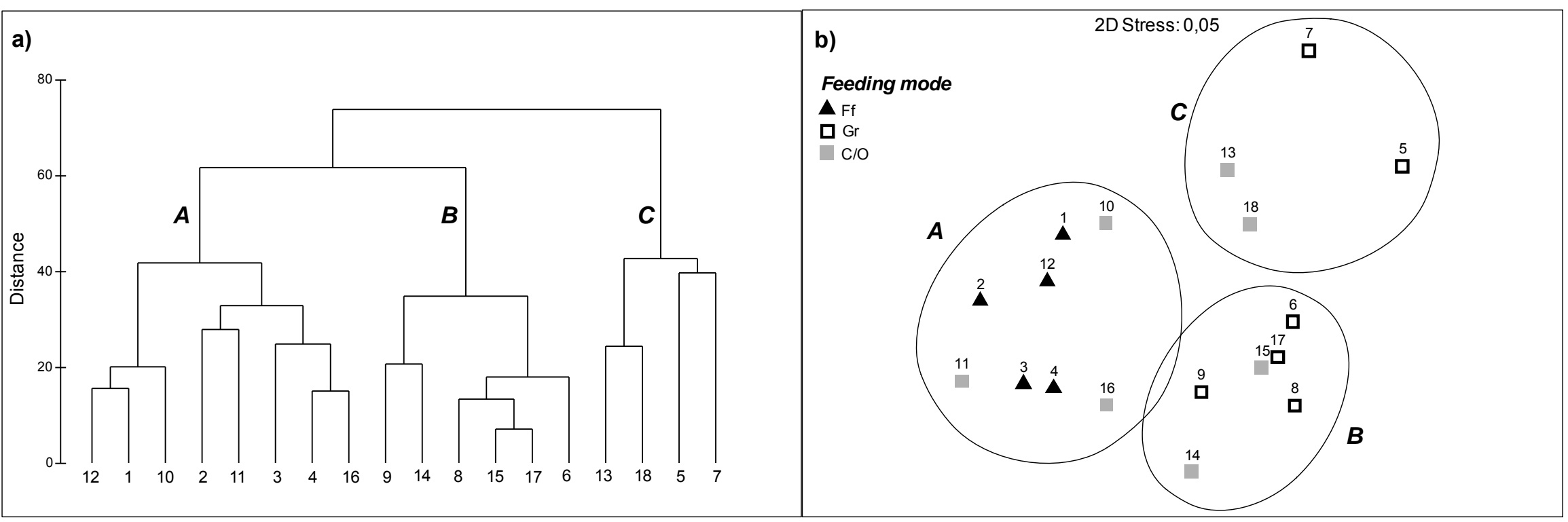

